\title{
The Impacts of Black Soldier Fly Frass on Nitrogen Availability, Microbial Activities, C Sequestration, and Plant Growth
}

\section{OPEN ACCESS}

Edited by:

Florian Wichern

Rhine-Waal University of Applied

Sciences, Germany

Reviewed by:

Christian Zurbrügg,

Swiss Federal Institute of Aquatic Science and Technology, Switzerland

Evans Nyakeri,

Jaramogi Oginga Odinga University of

Science and Technology, Kenya

*Correspondence:

Mesfin T. Gebremikael

mesfin.gebremikae/@food.au.dk

Specialty section

This article was submitted to

Waste Management in

Agroecosystems,

a section of the journal

Frontiers in Sustainable Food Systems

Received: 15 October 2021

Accepted: 12 January 2022

Published: 02 March 2022

Citation:

Gebremikael MT, Wickeren NV Hosseini PS and De Neve S (2022) The Impacts of Black Soldier Fly Frass

on Nitrogen Availability, Microbial

Activities, C Sequestration, and Plant

Growth

Front. Sustain. Food Syst. 6:795950.

doi: 10.3389/fsufs. 2022.795950

\author{
Mesfin T. Gebremikael ${ }^{1 *}$, Niklas van Wickeren ${ }^{2}$, Pezhman S. Hosseini ${ }^{2}$ and \\ Stefaan De Neve ${ }^{2}$
}

${ }^{1}$ Department of Food, Åarhus University, Åarhus, Denmark, ${ }^{2}$ Department of Environment, Ghent University, Ghent, Belgium

Using insects, notably black soldier fly (BSF), is becoming one of the emerging technologies to valorize agrifood waste into high-value products, such as proteins for animal feed. Its market is expected to grow more rapidly following the new European legislation extending larvae protein use in poultry farming. The anticipated increase in larvae protein also results in a parallel increase in frass, a residue leftover after rearing the larvae and selling as a biofertilizer. Little is known about the impacts of frass made from different feedstocks used for raising the larvae on plant growth and soil quality. We set up an incubation and pot experiment to understand their effect on plant growth and soil quality and tested seven frass fertilizers made from various types of food waste and anaerobic digestate and potato pulp as reference materials using maize as a test plant. We found that the effect of frass on $\mathrm{N}$ availability and soil microbial quality significantly $(p<0.05)$ varied depending on the feedstock used for rearing the BSF larvae. N immobilization occurred up to more than 70 days, and $4-20 \%$ net $N$ was released at the end of the 103-day-long experiment. In line with $\mathrm{N}$ availability dynamics, most of the frass treatments did not significantly increase the plant growth. All frasses significantly increased the microbial biomass $C$ and enzyme activities. About $56-70 \%$ of the applied $\mathrm{C}$ in frass is estimated to be stable in the soil. Our data confirm that frass is a valuable product to improve soil quality but need to be applied with $\mathrm{N}$ sources that are readily available to avoid nutrient shortage during plant growth.

Keywords: chitinase, bioconversion, enzymes, $\mathrm{N}$ uptake, dehydrogenase, food waste, anaerobic digestate

\section{INTRODUCTION}

About one-third of the food produced globally, which amounts to 1.3 billion tons per year, turns into waste (Gustavsson et al., 2011). In Europe, each citizen is estimated to make half a ton of waste annually (EC, 2020). Bedoic et al. (2019) estimated around 18.4 billion tons of agricultural wastes, co-products, and by-products in the EU between 2010 and 2016. It has long been recognized that waste disposals result in the loss of valuable resources and environmental pollution, such as ground and surface water pollution and greenhouse gas emissions-for example, the whole life cycle of food wastes accounts for 3\% of the total European greenhouse gas emissions (EC, 2010), thus adding significantly to climate change. Mitigating the consequences of climate change and feeding the growing world population necessitates a shift from a linear to a circular economy (Bonviu, 2014), which strives to prevent, valorize, and recycle wastes and create a zero-waste society. 
Several technologies have been innovated to recycle and valorize different types of wastes, particularly agrifood waste. Anaerobic digestion and insect rearing are widely applied to treat wastes from the agrifood processing industry. The use of insects, particularly Hermetia illucens L. (black soldier fly, BSF), is one of the emerging biowaste treatment technologies with several advantages. Firstly, BSF is a non-pest fly that turns tons of organic wastes into larval biomass within 2-4 weeks (Diener et al., 2009). Secondly, the protein made by black soldier fly larvae (BSFL) has been a valuable source of dietary protein, replacing fishmeal and soybean meal in fish and poultry farming (Madibana et al., 2020; Mwaniki et al., 2020). A recent review shows that BSFL biomass contains $32-58 \%$ proteins and $15-39 \%$ lipids in dry matter and that the protein can increase to $55-65 \%$ following the partial removal of lipids (Gold et al., 2018). Thirdly, the frass, which refers to the mixture of insect excretions, exoskeletons, and substrate residue leftover at the end of larval growth, has been used as a soil amendment and fertilizer, showing its potential to closing the nutrient cycling loop (Poveda, 2021). Recent reports have also shown the potential of replacing commercial peat with BSF frass in potted vegetable crop production without abiotic stress (Setti et al., 2019; Tan et al., 2021).

The insect frass, which is considered as an inevitable byproduct remaining at the end of larvae development, accounts for a significant portion (55-76\%) of the initial waste biomass (Diener et al., 2009). In line with the rapid growth of the insect industry globally (Van Huis, 2020), several companies sell frass as fertilizer and soil conditioner (Halloran et al., 2016), and its production in the $\mathrm{EU}$ is estimated to reach 1.5 million tons by mid-2020s (IPIFF, 2019). The quantity of frass is expected to increase further due to the growing demand in waste recycling and policies toward enhancing the circular economy, such as the EU Green Deal Policy (EC, 2020), indicating the need for research on the sustainable use of frass in agriculture.

Several studies have so far been conducted to increase our knowledge on the mass rearing of insects, focusing mainly on improving the bioconversion rate, larval weight, and composition (Gold et al., 2018). Despite the expected large quantity and growing market (Halloran et al., 2016), less attention is given to the by-product frass. To properly utilize the frass in a sustainable way, their effect on soil health and plant growth should be evaluated. The very limited studies available to date have shown that the application of frass increases yield (Rosmiati et al., 2017; Houben et al., 2020, 2021), activates plant defense responses against abiotic (Poveda, 2021) and biotic stress (Quilliam et al., 2020), and improves soil microbial activities (Gebremikael et al., 2020). On the contrary, few other studies found negative effects of BSF frass and other commercially available frass on soil quality and plant growth, such as phytotoxicity (Alattar et al., 2016; Watson et al., 2021a,b) and excessive nitrite accumulation in soil (Watson et al., 2021a).

These contrasting effects can be attributed to the differences in substrate composition and the feeding rate of the substrate to the larvae, which could increase the ratio of the undigested substrate in the frass (Diener et al., 2009; Gold et al., 2018). A previous study reported the impact of substrate composition on the quality of mealworm frass and its effect on plant growth (Poveda et al.,
TABLE 1 | Description of the bio-based fertilizers tested under lab conditions.

\begin{tabular}{|c|c|}
\hline Code & $\begin{array}{l}\text { Substrates used for rearing BSF larvae, AD, and } \\
\text { potato pulp }\end{array}$ \\
\hline PoF & $80 \%$ potato waste $+20 \%$ brewing by-product (BG) \\
\hline PoMrF & $40 \%$ potato waste $+40 \%$ mushroom stalk $+20 \%$ BG \\
\hline OrF & $80 \%$ orange/mandarin/clementine waste $+20 \%$ BG \\
\hline OrBrF & $\begin{array}{l}40 \% \text { orange/mandarin/clementine waste }+40 \% \\
\text { beetroot peelings }+20 \% \text { BG }\end{array}$ \\
\hline CKF & $100 \%$ chicken feed waste \\
\hline VegF & $\begin{array}{l}100 \% \text { vegetable food wastes collected from } \\
\text { supermarkets }\end{array}$ \\
\hline \multirow[t]{2}{*}{ ComF } & $\begin{array}{l}\text { Commercially available frass made from general food } \\
\text { waste }\end{array}$ \\
\hline & Other potential fertilizers tested as a reference \\
\hline$A D$ & A liquid anaerobic digestate made from food waste \\
\hline PoPulp & Potato pulp powder from starch-processing industries \\
\hline
\end{tabular}

2019). A substrate with high fiber content has also been reported to reduce the performance of the biowaste conversion process, as it is likely that BSFL do not have enzymes for the decomposition of fibers (Gold et al., 2018). The digestibility of the substrate can significantly impact the suitability of the BSF frass as a biofertilizer and soil amendment. To the best of our knowledge, no study has investigated the effect of different BSF frass made from substrates with varying compositions.

Given that the residue of the substrate has a significant proportion in the frass, its effect on plant growth, particularly on nutrient availability, may vary (Poveda et al., 2019; Gebremikael et al., 2020). Recently, we reported significant differences in $\mathrm{C}$ and $\mathrm{N}$ mineralization, quantity, and duration of $\mathrm{N}$ immobilized during an incubation experiment between frasses made from vegetable food waste and general food waste (Gebremikael et al., 2020). Data on the dynamics of nutrient availability over time is essential to increase nutrient use efficiency and reduce environmental impacts, such as ground water pollution through nitrate leaching. However, research on the actual effects of frass on soil, environment, and plants is rare.

The current study investigates the effect of BSF frasses made from various waste substrates on carbon and nitrogen dynamics and plant growth. We hypothesized that the effect of frass on the dynamics of $\mathrm{C}$ mineralization, $\mathrm{N}$ availability, and subsequent $\mathrm{C}$ sequestration and plant growth varies depending on the feedstock composition used for growing BSFL. We set up an experiment using seven different frass materials made from various proportions of agricultural and food processing wastes and maize as a test plant to test this hypothesis.

\section{MATERIALS AND METHODS}

\section{Soil Preparation}

Composite soil samples were collected from an agricultural field in Beitem, Belgium ( $50^{\circ} 55^{\prime} 18^{\prime \prime} \mathrm{N}, 3^{\circ} 07^{\prime} 58^{\prime \prime} \mathrm{E}$ ), which was harvested of maize, and the farmer had sown grass as a cover crop. The soil samples were taken from the top $15-\mathrm{cm}$ layer 
TABLE 2 | Fertilizer application rates for the pot experiment as expressed in fresh weight (FW) and dry matter (DM), percentage of nitrogen and carbon content of fertilizers based on dry matter (\% $\mathrm{N}$ and $\% \mathrm{C})$, and the rate of applied $\mathrm{C}\left(\mathrm{kg} \mathrm{C} \mathrm{ha}^{-1}\right)$ corresponding to $150 \mathrm{~kg} \mathrm{~N}^{-1}$ in each treatment.

\begin{tabular}{|c|c|c|c|c|c|c|c|}
\hline Treatments & $\begin{array}{c}\text { FW } \\
\left(\mathrm{t} \mathrm{ha}^{-1}\right)\end{array}$ & $\begin{array}{c}\text { DM } \\
\left(\mathrm{t} \mathrm{ha}^{-1}\right)\end{array}$ & $\begin{array}{c}\text { DM } \\
\text { (\%FM) }\end{array}$ & $\begin{array}{c}\% C \\
\text { (DW) }\end{array}$ & $\begin{array}{c}\% N \\
(\mathrm{DW})\end{array}$ & C:N & $\begin{array}{c}\text { C } \\
\left(\mathrm{kg} \mathrm{ha}^{-1}\right)\end{array}$ \\
\hline PoF & 4.6 & 4.3 & 92.0 & 42.0 & 2.3 & 18.4 & 1,790 \\
\hline PoMrF & 3.0 & 2.8 & 93.1 & 41.4 & 3.4 & 12.0 & 1,171 \\
\hline OrF & 3.3 & 3.0 & 90.1 & 46.3 & 3.3 & 14.1 & 1,375 \\
\hline OrBrF & 3.1 & 2.9 & 94.5 & 45.1 & 3.4 & 13.3 & 1,301 \\
\hline CKF & 4.7 & 3.3 & 70.5 & 48.1 & 2.9 & 16.4 & 1,596 \\
\hline VegF & 6.4 & 3.8 & 59.7 & 43.6 & 2.5 & 17.2 & 1,674 \\
\hline ComF & 8.0 & 4.8 & 60.5 & 46.6 & 2.0 & 23.0 & 2,246 \\
\hline$A D$ & 26.7 & 1.9 & 7.2 & 31.0 & 5.1 & 6.1 & 594 \\
\hline PoPulp & 11.2 & 10.0 & 89.7 & 47.2 & 1.0 & 48.5 & 4,727 \\
\hline
\end{tabular}

by sampling in a zigzag pattern, and the soil was thoroughly mixed and air-dried in the lab. The air-dried soil was then sieved through a 2-mm-wide mesh and stored at room temperature until the start of the experiment. The soil has a sandy loam texture and is characterized by a $\mathrm{pH}(\mathrm{KCl})$ of 5.6 and an organic carbon content of $1.1 \%$.

\section{Characterization of Potential Bio-Based Fertilizers}

In addition to frass fertilizers, liquid anaerobic digestate (AD) from food waste and a potato pulp (PoPulp) were assessed in this study as a reference to processed and unprocessed products. The different frass fertilizers were purchased from AgriGrub (UK), a company that produces and sells frass as a soil amendment. The frass fertilizers were produced by growing BSFL on a range of agricultural and food wastes (Table 1). The frasses were then dried in an oven at $80^{\circ} \mathrm{C}$ and milled to $1-\mathrm{mm}$ particle size. Before the experiments, the total carbon, the total and mineral nitrogen content, and the water content of each fertilizer were determined (Table 2).

\section{Experimental Setup}

Three separate experiments were conducted: two incubation experiments without plants under lab conditions to determine the potential $\mathrm{C}$ and $\mathrm{N}$ mineralization potential of selected $\mathrm{BBF}$ and a pot experiment with maize as a model plant.

\section{Carbon Mineralization}

For the carbon mineralization experiment, 21 PVC tubes $(r$ $=3.4 \mathrm{~cm}$ and $h=7.2 \mathrm{~cm}$ ) were filled with preincubated soil equivalent to $265 \mathrm{~g}$ of dry soil thoroughly mixed with the corresponding amount of each bio-based fertilizer. Only six of the nine treatments mentioned in Table 1 were considered as C mineralization from VegF, CKF, and PoPulp as had already been determined in our previous study (Gebremikael et al., 2020). The bio-based fertilizers were applied based on a fixed target $\mathrm{N}$ application rate of $150 \mathrm{~kg} \mathrm{~N} \mathrm{ha}^{-1}$ and adjusted to $0.11 \mathrm{~g} \mathrm{~N}$ $\mathrm{kg}^{-1}$ dry soil, considering the quantity of the soil per tube. The soil-fertilizer mixture was gently compacted to a height of $5 \mathrm{~cm}$ to reach a bulk density of $1.46 \mathrm{~g} \mathrm{~cm}^{-3}$. The same amount of soil without the addition of fertilizers was filled in three tubes (unamended control) to monitor $\mathrm{C}$ mineralization from the native soil organic matter.

Each of the filled PVC tubes was then placed in glass jars $(1.5 \mathrm{~L})$ together with a vial containing $15 \mathrm{ml}$ of $1 \mathrm{M} \mathrm{NaOH}$. The jars were then sealed airtight and placed in an incubator at $16^{\circ} \mathrm{C}$. After $24 \mathrm{~h}$, the $\mathrm{CO}_{2}$ trapped in the vial containing $\mathrm{NaOH}$ was determined by back-titrating the excess $\mathrm{NaOH}$ with $0.5 \mathrm{M}$ $\mathrm{HCl}$ after precipitating the carbonates with $1 \mathrm{ml}$ of $1 \mathrm{M} \mathrm{BaCl}_{2}$. During and after titration, the jars were left open for about $3 \mathrm{~h}$ to replenish the soil with oxygen before they were sealed airtight and returned back to the incubation chamber. To monitor the dynamics of $\mathrm{C}$ mineralization over time, the same procedure was followed to capture $\mathrm{CO}_{2}$ and back-titrate the excess $\mathrm{NaOH}$ in short time intervals at the beginning of the experiment and in longer intervals toward the end of the experiment (days 1, 3, 6, $14,21,28,35,44,52,60,71,80,93$, and 106). Two glass jars containing only the vial with $\mathrm{NaOH}$ were also included to correct $\mathrm{CO}_{2}$ in ambient air. The moisture content of each PVC tube was kept at 50\% water-filled pore space (WFPS) throughout the experiment by adding distilled water.

The net cumulative $\mathrm{C}$ mineralized from the treatments $\left[\mathrm{Cmin}_{\text {net }}(\%)\right]$ was calculated by subtracting the cumulative $\mathrm{C}$ of the unamended control (Cmin_untreated) from the cumulative $\mathrm{C}$ of the sample with the respective fertilizer (Cmin_treated) and divided by the total added $\mathrm{C}$ (Equation 1).

$\mathrm{Cmin}_{\text {net }}(\%)=\frac{\text { Cmin_treated }- \text { Cmin_untreated }}{\text { Total added } \mathrm{C} \text { in the bio }- \text { based fertilizers }} \times 100$

Furthermore, the humification coefficient was calculated by fitting the $\mathrm{C}$ mineralization data to a second-order kinetics model (Equation 2) (Sleutel et al., 2005).

$$
C(t)=C_{A}-\frac{C_{A}}{1+k_{2} a(1-a) C_{A} t}
$$

where $C(t)$ is cumulative net $\mathrm{C}$ mineralized at time $t, \mathrm{C}_{\mathrm{A}}$ is the amount of mineralizable $\mathrm{C}, k_{2}$ is the second-order 
mineralization rate constant, $a$ is the fraction of $\mathrm{C}$ incorporated into microbial biomass $\mathrm{C}$, and $k_{2} \mathrm{a}(1-\mathrm{a})$ is estimated as a lumped parameter because the individual parameters cannot be estimated separately.

Using a temperature dependence model of $\mathrm{C}$ mineralization (Deneve et al., 1996), we calculated the length of incubation at $16^{\circ} \mathrm{C}$ that would be equivalent to 1 year under field conditions (at an average soil temperature of $10^{\circ} \mathrm{C}$ ), which was 175 days. Fitting the 2nd-order kinetics model to the measured percentage of net cumulative $\mathrm{C}$ mineralized allowed us to calculate the cumulative percentage of organic $\mathrm{C}$ that would be mineralized during 175 days of incubation, equivalent to 1 year under field conditions (Sleutel et al., 2005). The humification coefficient $(h)$ is then considered as the difference (100 - \% net cumulative C mineralized until day 175). It is an estimate of the stable organic $\mathrm{C}$ in the bio-based fertilizers and their contribution to $\mathrm{C}$ sequestration.

\section{Nitrogen Mineralization}

To assess the $\mathrm{N}$ mineralization potential and impacts of the bio-based fertilizers on the microbial communities and their activity dynamics, experimental units were prepared by filling up PVC cores $(r=2.3 \mathrm{~cm}, h=18 \mathrm{~cm})$ with $225 \mathrm{~g}$ (dry mass) of preincubated soil thoroughly mixed with the corresponding amount of the bio-based fertilizers and gently compacting them to $10 \mathrm{~cm}$ to create a bulk density of $1.35 \mathrm{Mg} \mathrm{m}^{-3}$. The quantity of each fertilizer added to the corresponding treatments was calculated based on a fixed fertilizer application rate of $150 \mathrm{~kg} \mathrm{~N}$ $\mathrm{ha}^{-1}$, which is equivalent to $0.11 \mathrm{~g} \mathrm{~N} \mathrm{~kg}^{-1}$ dry soil, considering the quantity of soil filled per tube.

A total of 126 PVC cores $(7$ treatments $\times 3$ replicates $\times 6$ sampling times) were filled. The nitrogen mineralization of VEG, CKF, and PoPulp was already determined in our previous experiments (Laboan, 2018). Three replicates of each treatment and the control soil were destructively sampled at 12 , $26,40,54,68$, and 103 days after the start of the incubation to measure mineral $\mathrm{N}$. The mineral nitrogen content of the samples was extracted from $20 \mathrm{~g}$ of moist soil in $100 \mathrm{ml}$ of $1 \mathrm{M} \mathrm{KCl}$ after shaking for $1 \mathrm{~h}$. The total mineral $\mathrm{N}\left(\mathrm{NH}_{4}^{+}\right.$ and $\mathrm{NO}_{3}^{-}$) concentration in the extract was determined with a continuous flow analyzer (Chem-lab 4, Skalar 223 Analytical, Breda, Netherlands). The net mineral $\mathrm{N}$ from the added biobased fertilizers was calculated as the difference between total mineral $\mathrm{N}$ in the samples with fertilizers and in the unamended control sample and expressed as a percentage of the total $\mathrm{N}$ added from the bio-based fertilizers (Equation 4) (Deneve and Hofman, 1996).

$\operatorname{Nmin}_{\text {net }}(\%)=\frac{\text { Nmin_treated }- \text { Nmin_untreated }}{\text { Total added } \mathrm{N} \text { in the biobased fertilizers }} \times 100$

\section{Soil Microbial Parameters \\ Microbial Biomass Carbon and Enzymes}

The dynamics of selected microbial properties were monitored during the $\mathrm{N}$ mineralization incubation experiment. Microbial biomass $\mathrm{C}(\mathrm{MBC})$ was determined from $30 \mathrm{~g}$ of soil by fumigation and extraction method (Vance et al., 1987) with a TOC/TN analyzer (Skalar Analytical BV). The extraction efficiency coefficient used for microbial biomass carbon was 0.45 (Joergensen, 1996). Dehydrogenase activity (DHA) was analyzed using $5 \mathrm{~g}$ of moist soil and triphenyl tetrazolium chloride as a substrate, as explained in our previous study (Gebremikael et al., 2015). Chitinase activity (CHA) was measured according to Rodriguezkabana et al. (1983) as modified by Rossner (1991). The soil sample with an added chitin suspension was incubated for $17 \mathrm{~h}$ at $37^{\circ} \mathrm{C}$. Afterwards, the liberated $\mathrm{N}$-acetyl glucosamine was extracted with a $\mathrm{KCl}$ solution and determined spectrophotometrically at $585 \mathrm{~nm}$ (UV-VIS, Varian Cary 50 spectrophotometer, Palo Alto, United States).

\section{Pot Experiment}

Maize was grown in soil amended with the bio-based fertilizers in a greenhouse. Each Magenta jar $\left(9 \times 6.5 \times 6.5 \mathrm{~cm}^{3}\right)$ was filled with preincubated soil, equivalent to $312 \mathrm{~g}$ dry weight, that was thoroughly mixed with the bio-based fertilizers at a rate of $150 \mathrm{~kg} \mathrm{~N} \mathrm{ha}{ }^{-1}$, which is a common $\mathrm{N}$ fertilizer dose for maize in the region. The amount of the fertilizers to be added was calculated, taking into account the surface area and the depth of the soil filled in the pot. The soil was then gently pressed to achieve a bulk density of $1.35 \mathrm{Mg} \mathrm{m}^{-3}$. A total of 50 pots, that is, the nine fertilizers described above and one control treatment containing only soil, were assessed in five replicates. The maize seeds (Zea mays L., variety: NK Falkone; Aveve, Leuven, Belgium) were pregerminated by placing them between moistened papers for 5 days before the start of the experiment. The germinated seeds were transplanted into each pot (one plant per pot) to a depth of $2 \mathrm{~cm}$. Afterwards, distilled water was added to each pot to reach $50 \%$ WFPS, and the weight of the pot was noted. To guarantee that the pots contain the same amount of water, the initial water contents of the fertilizers were taken into account.

Given the small size of the pot, the maize plants were left to grow for 62 days until $\mathrm{N}$ deficiency symptoms started to develop. For the first 34 days, the pots were placed in a growth chamber at $18^{\circ} \mathrm{C}$ with a light regime of $16 / 8$. Afterwards, the pots were transferred to a greenhouse $\left(20^{\circ} \mathrm{C}\right.$ with a light regime of $16 / 8$ ) because the maize started to reach the top of the shelf. In the greenhouse, the maize was further allowed to grow for 28 days. Every 2-3 days, the maize was watered by adding distilled water until the initial weight of the pot was reached. To prevent ventilation effects, the pots were moved twice a week to a different position. To prevent damage of the plants by insects, spraying with pesticides was conducted once a week in the growth room and when necessary in the greenhouse.

At the end of the experiment (harvest), the soil was separated from the plant material. The plant samples were weighed as fresh and after drying at $60^{\circ} \mathrm{C}$ for 3 days. Total nitrogen in the dried plant biomass was determined by an elemental analyzer (Variomax CNS analyzer, Elementar, Germany). Nitrogen uptake was calculated as the total $\mathrm{N}$ in the aboveground plant biomass per pot. The soil was sieved through a mesh $(3 \mathrm{~mm})$ to separate fine roots. The collected soil was then stored 


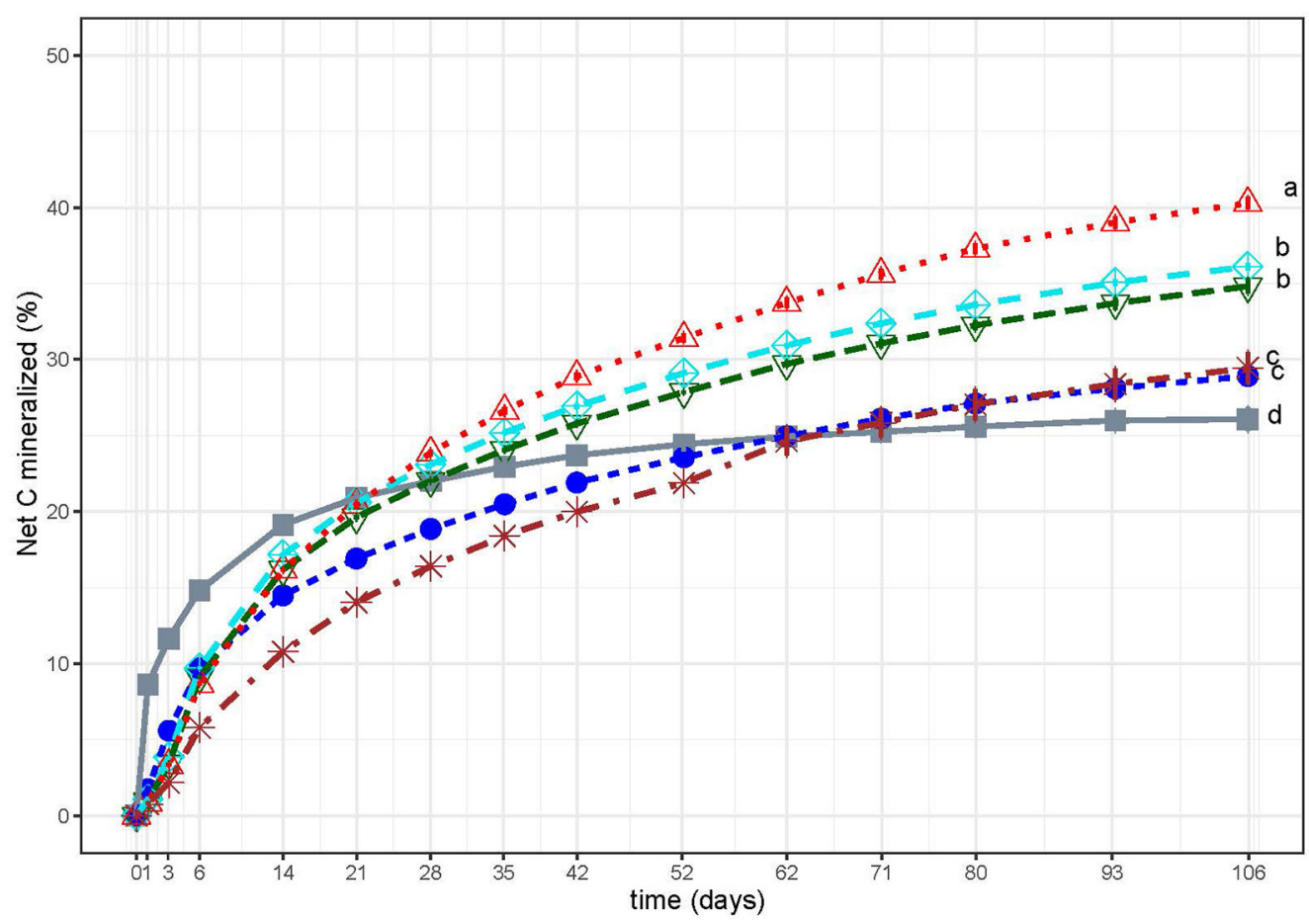

Treatments

- $A D$

- ComF $\nabla$ OrBrF

$\triangle$ OrF

으 PoF

* PoMrF

FIGURE 1 | The dynamics of cumulative net $\mathrm{CO}_{2}-\mathrm{C}$ mineralized from bio-based fertilizers are expressed as a percentage of total organic $\mathrm{C}$ added in each treatment. Different letters show significant statistical differences as assessed at the end of the incubation $(p<0.05)$.

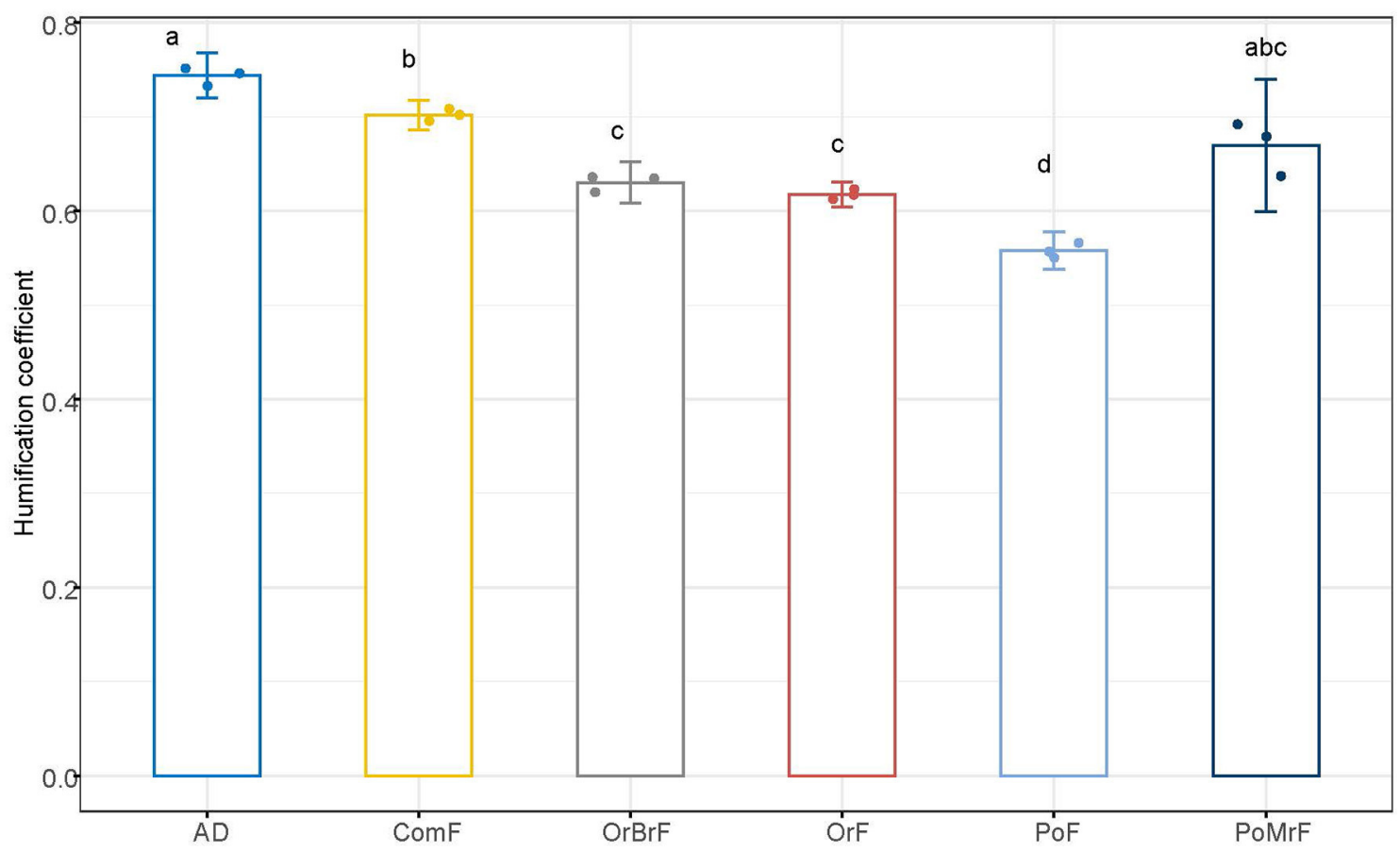

FIGURE 2 | Simulated humification coefficient referring to the fraction of stable $C$ left in the soil 1 year after the application of bio-based fertilizers under field conditions using the 2 nd-order kinetic model. Different letters show significant statistical differences $(p<0.05)$ between mean values $(n=3 \pm$ SE). 


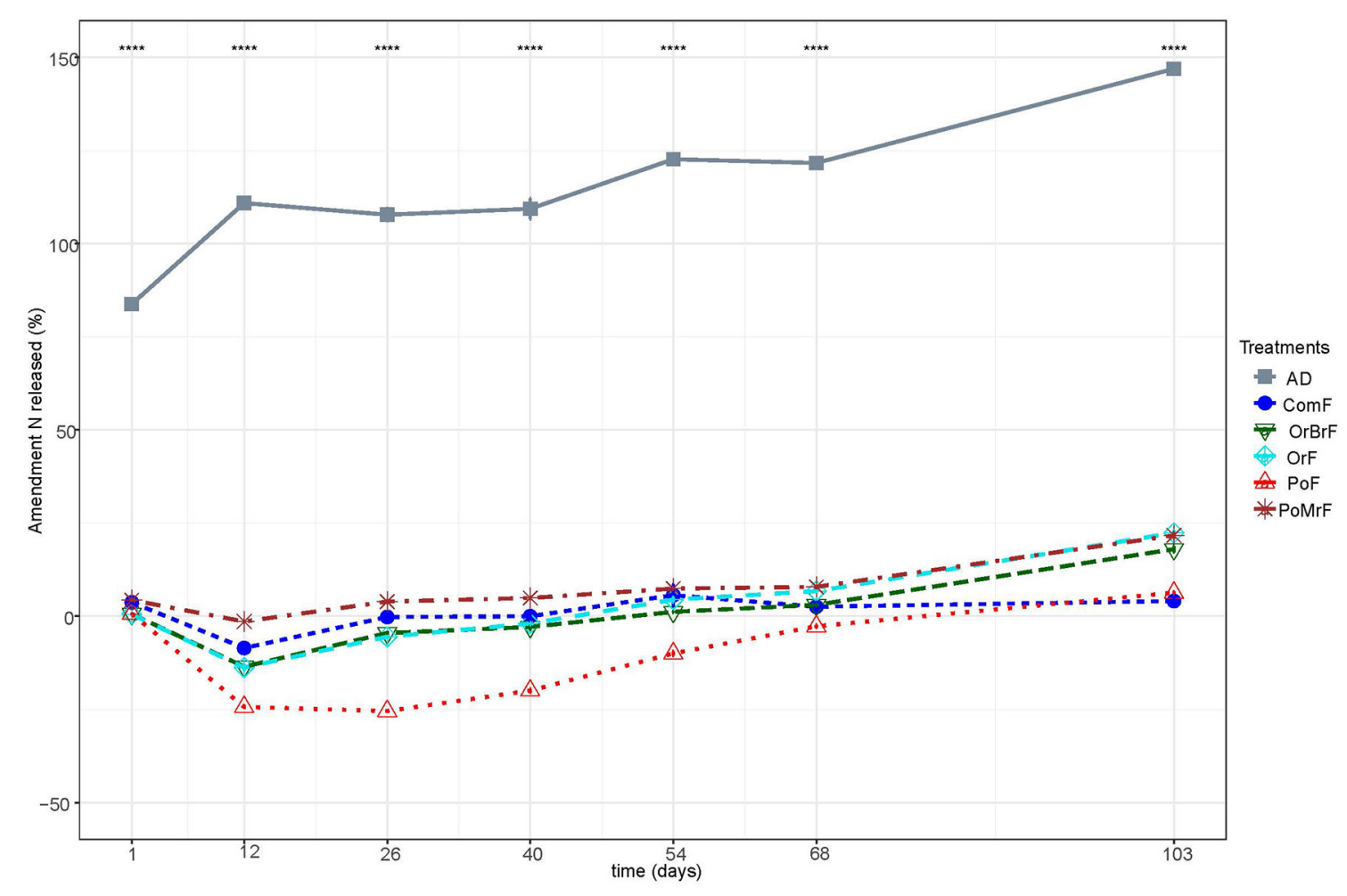

FIGURE 3 | Dynamics of net N released from the bio-based fertilizers expressed as a percentage of total $\mathrm{N}$ added in each treatment. ${ }^{\star \star \star *}$, significant statistical differences $(p<0.001)$.

at $4^{\circ} \mathrm{C}$ until mineral nitrogen, microbial biomass $\mathrm{C}$, and dehydrogenase activity were analyzed using the same procedure as explained above.

\section{Statistics}

A two-way analysis of variance model with two factors (biobased fertilizer treatments and incubation time) was run for each parameter of the $\mathrm{N}$ incubation experiment using aov function in R studio version 3.5.3 (Team, 2019). The assumptions for ANOVA were checked based on the residuals using the generic function plot, shapiro-test, and leveneTest. Because there were significant interactions between the two factors, the data was further split based on the incubation time. Analysis of variance was then conducted for each sampling time using a parametric one-way ANOVA model (aov) with the type of bio-based fertilizers as a factor. The post-hoc function TukeyHSD multiple comparisons of means was applied for ANOVA with $p<0.05$. Parameters with heteroscedastic data were fit to the conservative Welch's heteroscedastic F-test function (oneway.test) and a pairwise comparison using the conservative gamesHowellTest. When the assumption of normality was not fulfilled, nonparametric Kruskal-Wallis test was performed with a post-hoc function dunn.test with Bonferroni corrections for type I error. One-way ANOVA and post-hoc analysis was executed in the same way for the plant parameters of the pot experiment and the last sampling of the $\mathrm{C}$ mineralization experiment.

\section{RESULTS}

\section{Laboratory Incubation Experiments C Mineralization Dynamics}

The cumulative percentage of net $\mathrm{C}$ mineralized from the added bio-based fertilizer was significantly different after 106 days (Figure 1). The PoF showed the highest net $\mathrm{C}$ cumulative percentage at the end of the experiment (40\%). OrF and OrBrF showed similar net $\mathrm{C}$ cumulative percentages at the end of the experiment with 72 and $70 \%$, respectively. ComF and $\mathrm{AD}$ showed the lowest cumulative percentage of net $\mathrm{C}$ mineralization. The $\mathrm{AD}$ showed the highest net $\mathrm{C}$ mineralization at the start of the experiment and stabilized around day 52. In contrast, all the frass treatments continuously showed increasing net mineralization throughout the experiment.

The humification coefficient of the $\mathrm{AD}(0.74)$ calculated using the 2nd-order kinetics model was significantly higher than all other treatments except PoMrF (Figure 2). The frass treatments also showed significant differences in the humification coefficient. The ComF and PoMrF showed the highest humification coefficient of the frass treatments ( 0.70 and 0.67), with OrBrF and OrF following (0.63 and 0.62), and PoF exhibited the lowest humification coefficient (0.56).

\section{Nitrogen Mineralization}

While all the frass treatments immobilized $\mathrm{N}$ at the beginning of the experiment, the percentage of net mineral $\mathrm{N}$ released by 


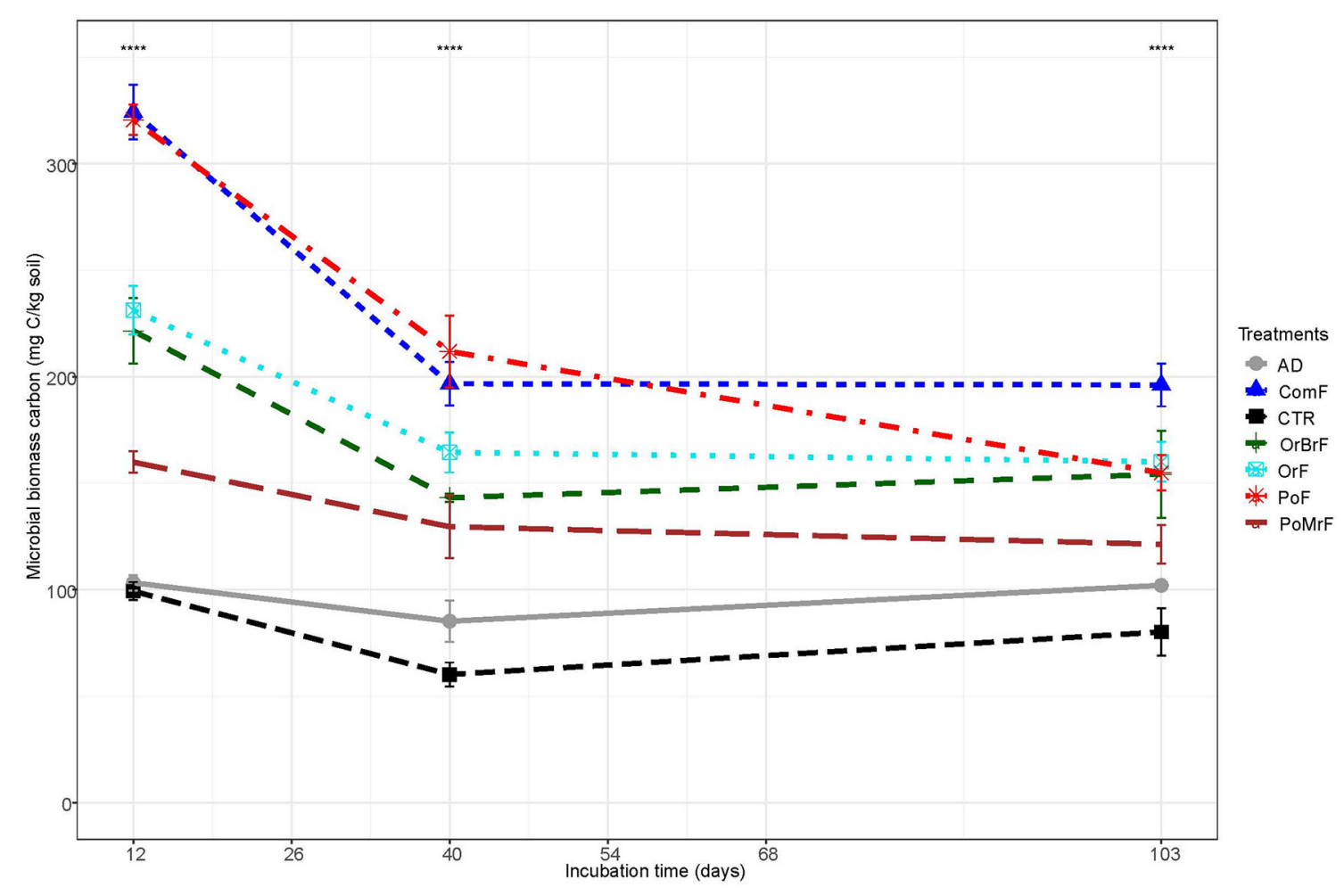

FIGURE 4 | Dynamics of microbial biomass $\mathrm{C}$ overtime during the incubation experiment under laboratory conditions. ${ }^{\star \star \star \star}$ refers to significant statistical differences $(p<0.001)$.

the $\mathrm{AD}$ reached more than $100 \%$ after 12 days and $148 \%$ by the end of the experiment (Figure 3). Among the frass fertilizers, PoMrF immobilized the least mineral $\mathrm{N}$ after 12 days, while PoF immobilized the most. OrF (22\%) and PotMrF (21.7\%) resulted in a significantly higher percentage of net $\mathrm{N}$ released compared to $\operatorname{OrBrF}(18 \%)$, PoF (6\%), and ComF (4\%).

\section{Microbial Biomass Carbon and Enzymes}

The MBC was significantly higher in frass treatments compared to the $\mathrm{AD}$ and unamended control at least until 40 days after the start of the incubation (Figure 4). All the frass treatments, except PoMrF, resulted in significantly higher $(p<0.05)$ MBC compared to the control (CTR) throughout the experiment. Significant differences were also observed among frass treatments. PoF and ComF showed the highest $(P<0.0001)$ MBC until 40 days after the start of the incubation. MBC was significantly higher $(p<$ 0.001) in PoF compared to PoMrF, while there was no significant difference between $\mathrm{OrF}$ and $\mathrm{OrBrF}(p>0.05)$.

All the frass treatments, except PoMrF, resulted in significantly higher DHA than the CTR and AD during the initial 12 days of incubation (Figure 5A). Unlike the MBC, the effect of frass treatments did not show significant differences during the later stages of incubation. PotF resulted in the highest increase (two- to three-fold) compared to the CTR, AD, and other frass treatments. PoMrF resulted in the lowest DHA activity of all the frass treatments, particularly during the first 40 days of incubation.
The CHA was significantly higher in frass treatments than in the CTR and $\mathrm{AD}$ at the beginning and end of the incubation period (Figure 5B). Significant differences in chitinase activity were also recorded among the frass treatments. ComF showed the highest chitinase activities compared to the other frass treatments on day 12. PoMrF resulted in the lowest chitinase activity compared to the other frass treatments on day 12 and at the end of the experiment.

\section{Greenhouse Plant Growth Experiment Plant Shoot Biomass}

The fresh maize plant shoot biomass was significantly higher in the $\mathrm{AD}$ and ComF than the CTR, while the PoPulp and PoPF resulted in significantly lower fresh shoot biomass than the CTR. The dry biomass in AD (2.25 $\pm 0.34 \mathrm{~g})$ treatment was significantly higher compared to all other treatments (Figure 6A). The frass treatments showed significant differences in dry shoot biomass (Figure 6B). The dry biomasses of OrF, PoPF, and PoPulp were significantly lower than the CTR and other frass treatments, except for CKF. Unlike the dry biomass, there were no significant differences in $\mathrm{N}$ uptake within the treatments or between the unamended control (Figure 7).

At the end of the pot experiment, the microbial biomass did not show significant differences, although the treatments tended to show slightly higher $\mathrm{MBC}$ than the unamended control (Figure 8A). In contrast to the $\mathrm{MBC}$, all the treatments resulted in a significantly higher dehydrogenase enzyme activity. 


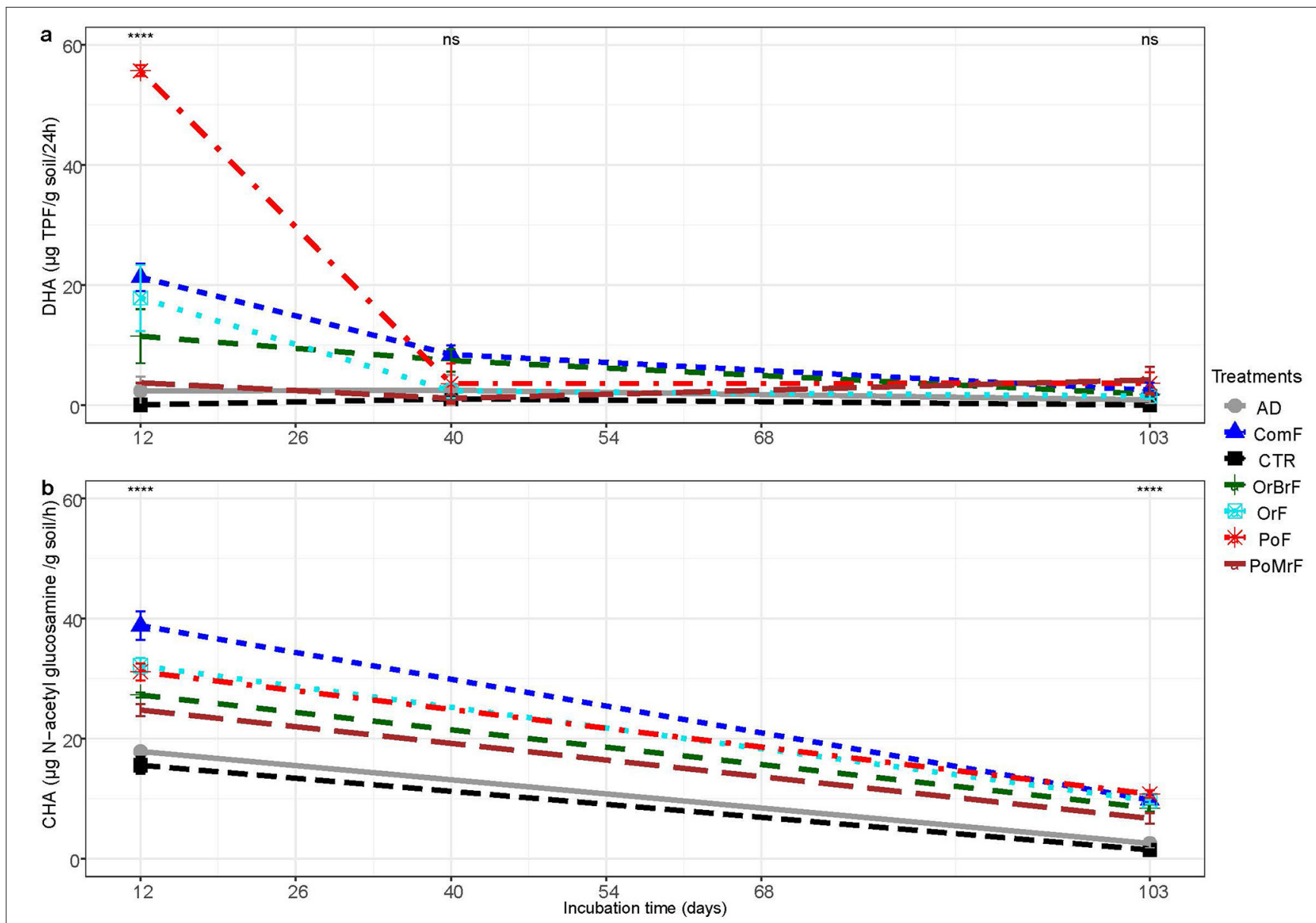

FIGURE 5 | Mean dehydrogenase (A) and chitinase (B) enzyme activities at a selected period of incubation ( $n=3 \pm$ SE). ${ }^{* * * *}$ and ns refer to statistically significant differences $(p<0.001)$ and no significant difference $(p>0.05)$.

The PoPulp treatment also showed the highest dehydrogenase enzyme activity (Figure 8B).

\section{DISCUSSION}

\section{Contribution to Stable Organic Carbon}

The frass treatments showed significant differences in net cumulative $\mathrm{C}$ mineralized and the simulated fraction of stable $\mathrm{C}$, indicating the role of feedstock used for rearing the larvae in building up the soil organic carbon stock. For example, PoMrF contributed a significantly higher $(+10 \%)$ fraction of stable $\mathrm{C}$ than the PoF. Although the PoF resulted in the lowest contribution to the stable soil organic C, it contributes $20 \%$ more stable $\mathrm{C}$ fraction than the raw potato pulp (Gebremikael et al., 2020), showing that valorizing potato pulp with BSFL could improve its quality as a soil amendment and subsequent role in $\mathrm{C}$ sequestration. There is a need to further analyze $\mathrm{CO}_{2}$ and other greenhouse gas emissions during frass production to accurately quantify the net contribution of frass to $\mathrm{C}$ sequestration (Rummel et al., 2021).
The chemical composition of the feedstock, such as cellulose, hemicellulose, and lignin fractions, influences $\mathrm{C}$ mineralization and the subsequent stable C fraction (Hemati et al., 2021). The significant differences in $\mathrm{C}$ mineralization and humification coefficient among the frass treatments can be attributed to differences in lignocellulosic fractions in the feedstocks or the frasses. However, no data was gathered on the lignocellulosic composition of BSF frass, as this was beyond the scope of the current study. The food waste $\mathrm{AD}$ in the current study showed the highest overall humification coefficient $(0.70)$, which is relatively lower than the crop residue digestate and pig slurry co-digested with vegetable crop residues as reported in our previous study (Gebremikael et al., 2020). Our findings consistently show that a higher fraction of $\mathrm{C}$ in the digestate becomes stable than in various BSFL frasses. Like the frass, the actual stable carbon fraction of the digestates can vary depending on the feedstock.

\section{The Dynamics of Nitrogen Availability}

The application of frass, in general, resulted in an initial net $\mathrm{N}$ immobilization that lasted 26-70 days after application. Eventually, 4 to $22 \%$ of total $\mathrm{N}$ became available, which is 


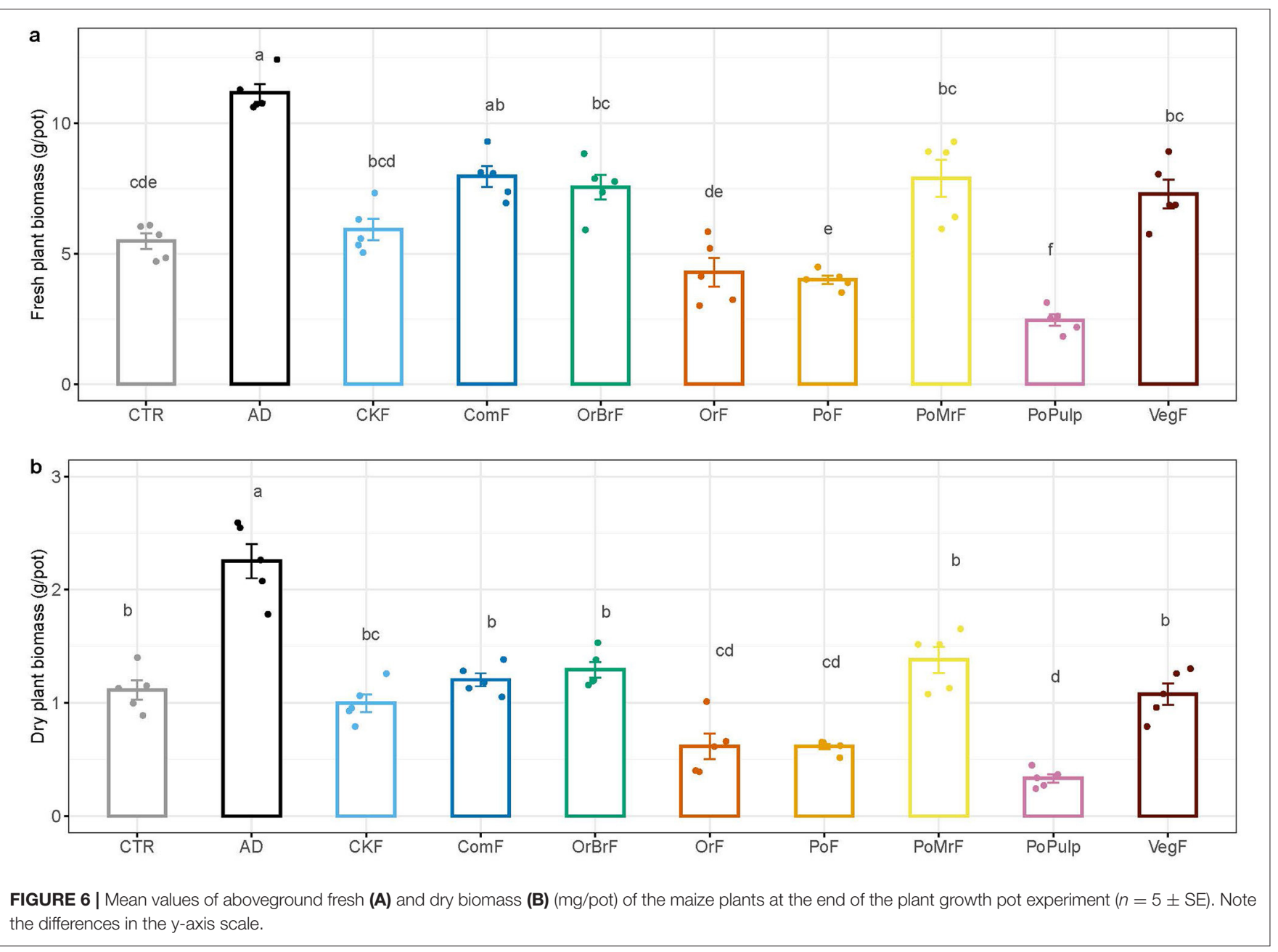

comparable to an estimated potential release of 5-25\% in mineral $\mathrm{N}$ form after the application of composts during the first year crop growth season (Prasad, 2009). Like in the composts, the magnitude and duration of $\mathrm{N}$ immobilization and net $\mathrm{N}$ released varied significantly among the frass treatments, indicating that the composition of the substrate used for rearing BSFL impacts $\mathrm{N}$ availability. Such impact is clearly observed with PoF that resulted in the highest net immobilization for more than 2 months, while PoMrF resulted in the highest net $\mathrm{N}$ released without net immobilization (Figure 3). Such contrasting differences in $\mathrm{N}$ availability could be attributed to the lower $\mathrm{C} / \mathrm{N}$ in PoMrF (12.1) than the PoF (18.4). However, a significant difference in net $\mathrm{N}$ availability was also recorded on day 40 and 68 between $\mathrm{OrF}$ and $\mathrm{OrBrF}$ despite their similar $\mathrm{C} / \mathrm{N}$, indicating the roles of other chemical and microbial properties of frass in determining nutrient availability (Poveda et al., 2019). It seems that a higher soluble $\mathrm{C}$ content in the frass is the main reason for the immobilization or slow net availability of $\mathrm{N}$ in the frass. A significantly higher $\mathrm{C}$ mineralization, dehydrogenase activity, and microbial biomass $\mathrm{C}$ in the frass treatments indicate the presence of more labile $\mathrm{C}$ in the frass than the AD. Previous studies reported that mealworm frass made from wheat bran had a high soluble C fraction (49\%) which could potentially result in $\mathrm{N}$ immobilization, particularly if there is no sufficient $\mathrm{N}$ in the frass or in the soil solution for the metabolism of the microbial communities (Houben et al., 2020).

Unlike the frasses, $\mathrm{AD}$ released the highest amount of net mineral $N$, which was mainly due to the high proportion of initial mineral $\mathrm{N}(63 \%)$ present in the material. Most of this mineral $\mathrm{N}$ was recovered at the first sampling event $(45 \%$ mineral $\mathrm{N}$ release after 12 days). A large $\mathrm{N}$ mineralization (total mineral $\mathrm{N}$ release close to $150 \%$ ) was observed by the end of incubation, suggesting that $\mathrm{AD}$ induced a significant priming effect, which is often described as the decomposition of native soil organic matter (SOM) due to an increased microbial activity after the application of additional energy sources through the organic fertilizer (Fontaine et al., 2003; Kuzyakov, 2010). The high N availability in the digestate probably stimulated the growth of $\mathrm{K}$-strategists (which grow slowly but degrade complex organic compounds), resulting in additional mineralization of $\mathrm{N}$ from the native SOM. The humification coefficient of the AD indicates that it consisted of about $75 \%$ stable carbon compounds that might have stimulated the growth of K-strategists. A recent study has also shown that the K-strategy bacterial phylum replaced 


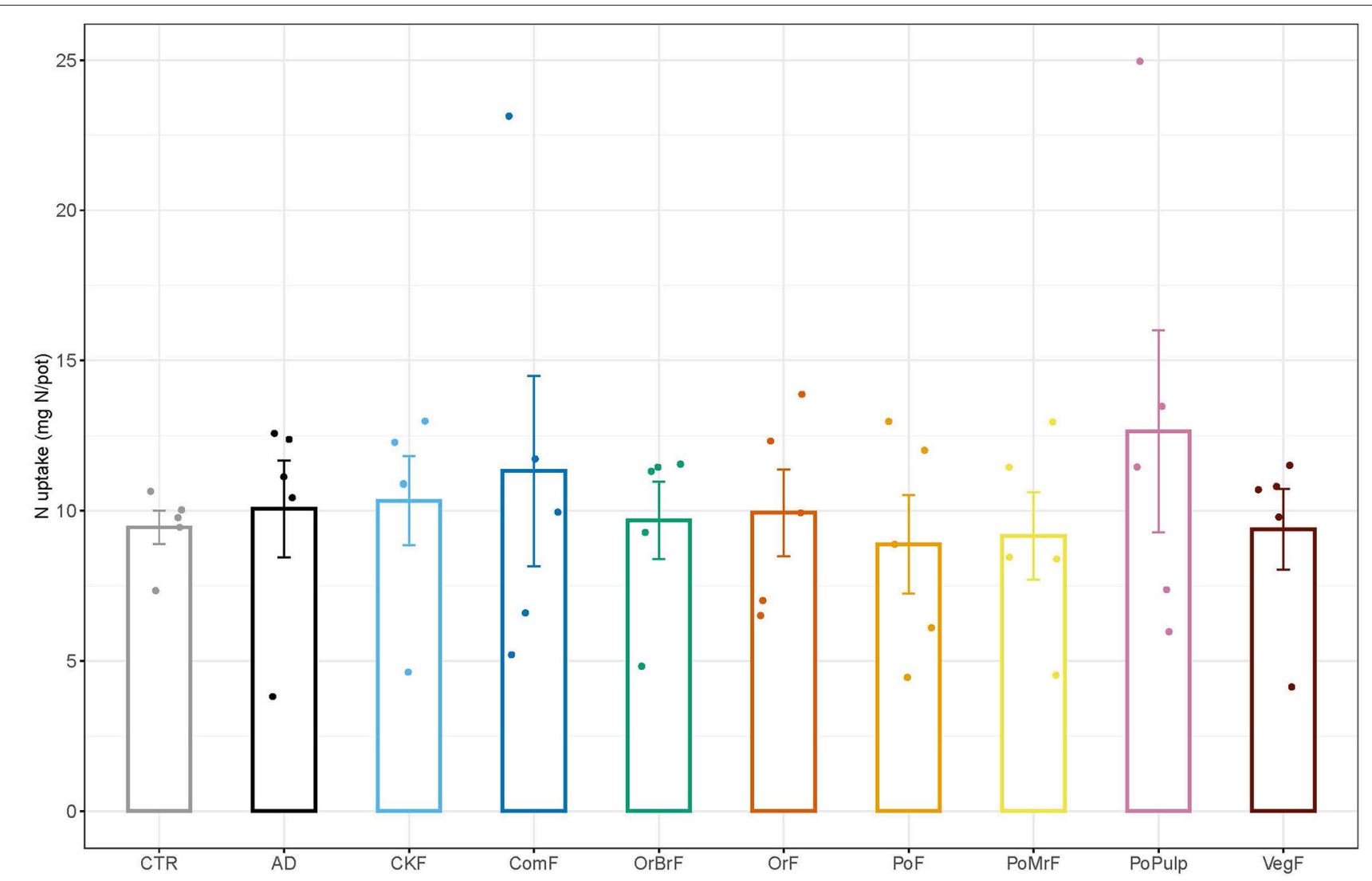

FIGURE 7 | Mean values of $\mathrm{N}$ uptake (mg/pot) of the maize plants at the end of the plant growth pot experiment $(n=5 \pm \mathrm{SE})$.

the r-strategy bacteria when assimilating labeled glucose in highnitrogen-availability conditions (Zhang et al., 2020).

\section{Microbial Biomass and Enzyme Activities}

Like the $\mathrm{C}$ and $\mathrm{N}$ mineralization, significant differences in $\mathrm{MBC}$ and DHA in the incubation experiment between the frass treatments indicate the role of the diet composition used for rearing the insects in the impact of frass on soil microbial activities. Poveda et al. (2019) reported that the microbial composition of frass depends on the diets that the mealworm $T$. molitor was feeding on. In contrast to the studies that reported the antimicrobial effect of specific compounds, such as phenolics in orange peels and beetroot wastes (Ruiz and Flotats, 2014; Calabrò et al., 2020), significantly higher MBC was recorded in OrF and $\mathrm{OrBrF}$ than the control and $\mathrm{AD}$.

The increased MBC could explain the immobilization of mineral $\mathrm{N}$ by the frass treatments. At the end of the experiment, the MBC was still significantly higher for all frass treatments than the control, suggesting that frass application could sustain the microbial biomass for a more extended period. However, the DHA decreased to low values from day 40 onward, and no significant differences between the treatments and the control were found, suggesting that a large part of the microbial biomass became dormant. Mainly slow-growing adapted K-strategists can be assumed to be active in the soil following the exhaustion of labile carbon compounds (Fontaine et al., 2003; Zhang et al., 2020). In contrast to frass, AD application had no significant effect on MBC in the current study (Figure 4) and in our previous study (Gebremikael et al., 2020), indicating the advantage of frass over $\mathrm{AD}$ in improving the soil biological quality and its functions.

In contrast to the expectation that root exudates would increase $\mathrm{MBC}$, the $\mathrm{MBC}$ was much lower in the pot compared to the incubation experiment, which could be explained by the likely nutrient limitation, particularly $\mathrm{N}$, in the pot experiment (Camenzind et al., 2018). However, DHA was higher in the presence of plants, indicating that the microbial oxidation could be enhanced by root exudates despite this potential nutrient limitation. Although there is a trend of increased MBC and DHA in the frass and other treatments compared to the control in the pot experiment, the differences were statistically significant only for the DHA. The significant increase in DHA at the end of the pot experiment indicates the potential of frass and the other treatments to enhance the microbial activity even under limited nutrient conditions.

The chitinase activity was significantly enhanced for all frass treatments compared to the control and the $\mathrm{AD}$ after 40 and 103 days. The higher chitinase activity could be linked to chitin, which is the predominant polysaccharide found in the shed exoskeletons of insects (Sharp, 2013) and also found in the frass. Chitin is also a major component of the cell wall of fungi and 

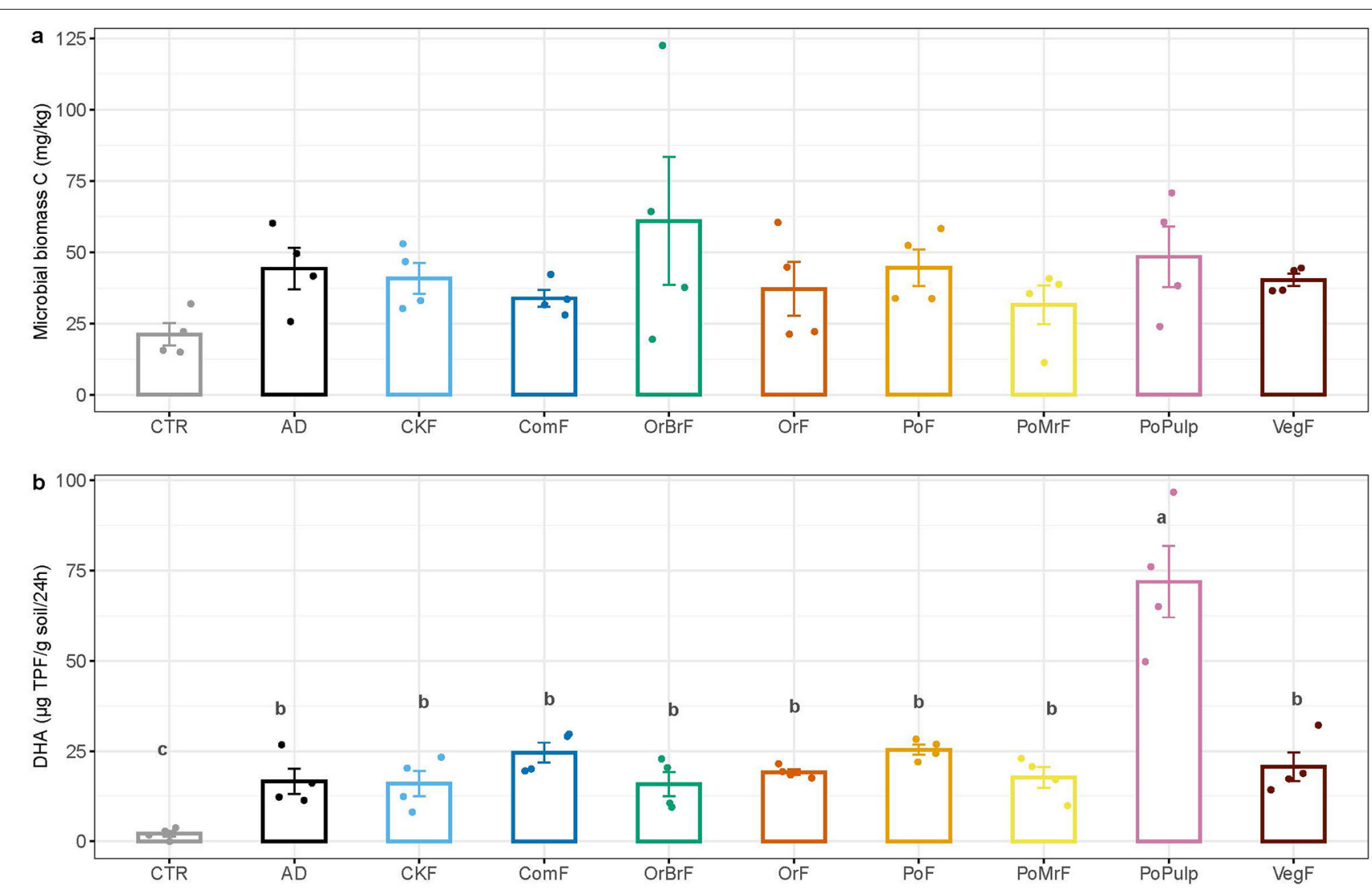

FIGURE 8 | Mean values of the microbial biomass $C(\mathbf{A})$ and dehydrogenase activity $\mathbf{( B )}$ at the end of the plant growth pot experiment $(n=4 \pm$ SE).

is prone to degradation by chitinase enzymes (Nagarajkumar et al., 2004). The production of extracellular chitinase enzymes is related to antifungal behavior (Zhang and Yuen, 2000). Our previous experiment showed that frass and digestates from pig slurry treatments significantly suppressed the development of Rhizoctonia solani in bean plants (Phaseolus vulgaris cv. Prelude) (Gebremikael et al., 2020). Unlike the frass treatments, the chitinase activity in the $\mathrm{AD}$ treatment was not significantly different from the control, suggesting that enzymatic lysis of fungal cell walls through extracellular chitinases is not a primary mechanism of the digestate in biocontrol.

\section{Plant Biomass and Nutrient Uptake}

The frass treatments can be broadly grouped in 3 categories based on fresh and dry biomass yield compared to the control, namely, with positive effect (ComF), no significant effect (CKF, OrBrF, and PoMrF), and adverse effect (OrF and PoF), further showing that the impact of frass on plant growth depends on the feedstock composition. The plant biomass seems generally related to the dynamics in net nutrient availability from each bio-based fertilizer. AD released a significant proportion of total $\mathrm{N}$ as net mineral $\mathrm{N}$ immediately following its application. The application of $\mathrm{AD}$ made mainly from dedicated energy crops and animal excrements has consistently increased the crop yield, particularly in pot experiments (Moller and Müller, 2012). Here AD from food waste resulted in a significant increase in maize yield, further confirming the potential of $\mathrm{AD}$ as a fertilizer.

Most of the frass treatments immobilized nitrogen during the first 2 months of the incubation experiment, corresponding to the 62 days of maize growing. $\mathrm{N}$ immobilization in the incubation experiment indicates that plant roots face an intense competition against the microbial communities for $\mathrm{N}$ in treatments with frass. The mineral $\mathrm{N}$ left in the soil at the end of the experiment was $<3 \mathrm{ppm}$ (data not shown), and no other additional nutrients were applied with the frass and the other amendments, indicating that nutrient availability was not optimal for plant growth. Unlike field experiments, the soil depth in the current experiment was not optimal for extended root growth, limiting the potential of roots to explore nutrients from deeper soil layers.

Previous studies that reported significant effects of mealworm frass on ryegrass (Lolium multiflorum Lam.) and barley (Hordeum vulgare L.) shoot biomass applied frass at a rate equivalent to $250-500 \mathrm{~kg} \mathrm{~N} \mathrm{ha}^{-1}$, which is much higher than the $\mathrm{N}$ required by the plants (Houben et al., 2020, 2021). A previous study also applied a high rate of frass (1:1 or $2: 1$ soil-to-frass ratio) and found significant effects on the growth of lettuce (Lactuca sativa var. Crispa) (Rosmiati et al., 2017). 
Given that we applied $150 \mathrm{~kg} \mathrm{~N} \mathrm{ha}^{-1}$ and the $\mathrm{N}$ immobilizing potential of the frasses, only a limited part of the $\mathrm{N}$ might have become mineralized. To avoid $\mathrm{N}$ deficiencies and reduce environmental pollution (e.g., nitrate leaching), future studies should investigate appropriate application rates based on the $\mathrm{N}$ mineralization rate dynamics of the frass and crop $\mathrm{N}$ demand.

Regardless of the type of frass and potential $\mathrm{N}$ mineralization pattern, no significant differences were observed in $\mathrm{N}$ uptake among the treatments and the control, suggesting that the frass application might have stimulated other mechanisms that could increase the $\mathrm{N}$ uptake efficiency. This is mainly observed in ComF that significantly increased fresh biomass despite the lowest (4\%) net $\mathrm{N}$ mineralization suggesting a non-nutritional effect of frass, such as stimulation of hormone production. Poveda et al. (2019) isolated more than 26 microbial strains in frass that produce auxins, which are the most important group of hormones involved in adventitious root formation (Rout, 2006), thus increasing nutrient uptake efficiency.

\section{CONCLUSION}

The effects of frass on soil microbial quality, C sequestration, and plant growth vary significantly depending on the substrate used to grow larvae. The application of frass consistently increased the microbial biomass and activity, confirming its potential in improving soil quality. Moreover, the high chitinase activity following frass application shows its potential to suppress fungal diseases, a quality that organic growers need.

Most of the frasses in the current study immobilize $\mathrm{N}$ after application and release, in general, net mineral $\mathrm{N}$ comparable to composts. Frass treatments with high $\mathrm{N}$ immobilization

\section{REFERENCES}

Alattar, M. A., Alattar, F. N., and Popa, R. (2016). Effects of microaerobic fermentation and black soldier fly larvae food scrap processing residues on the growth of corn plants (Zea mays). Plant Sci. Today 3, 57-62. doi: 10.14719/pst.2016.3.1.179

Bedoic, R., Cosic, B., and Duic, N. (2019). Technical potential and geographic distribution of agricultural residues, co-products and byproducts in the European Union. Sci. Total Environ. 686, 568-579. doi: 10.1016/j.scitotenv.2019.05.219

Bonviu, F. (2014). The european economy: from a linear to a circular economy. Romanian J. Eur. Aff. 14, 78-91. Available online at: https://doaj.org/article/ 14f3b5f27814475f9d92435ba6ad9a5f

Calabrò, P. S., Fazzino, F., Sidari, R., and Zema, D. A. (2020). Optimization of orange peel waste ensiling for sustainable anaerobic digestion. Renew. Energy 154, 849-862. doi: 10.1016/j.renene.2020.03.047

Camenzind, T., Hattenschwiler, S., Treseder, K. K., Lehmann, A., and Rillig, M. C. (2018). Nutrient limitation of soil microbial processes in tropical forests. Ecol. Monogr. 88, 4-21. doi: 10.1002/ecm.1279

Deneve, S., and Hofman, G. (1996). Modelling N mineralization of vegetable crop residues during laboratory incubations. Soil Biol. Biochem. 28, 1451-1457. doi: 10.1016/S0038-0717(96)00154-X

Deneve, S., Pannier, J., and Hofman, G. (1996). Temperature effects on Cand N-mineralization from vegetable crop residues. Plant Soil 181, 25-30. doi: $10.1007 /$ BF00011288 characteristics could also be used to catch otherwise lost $\mathrm{N}$ from fields after harvesting in late summer or in autumn. Most of the frasses in the present experiment seem to have no significant positive or negative effect on the vegetative growth of maize in a controlled pot experiment when applied with an equivalent $\mathrm{N}$ recommended rate at sowing, risking potential yield loss in the short term. It seems that frass should be applied well before planting or with supplemental $\mathrm{N}$ and other nutrients in the form of fast-release organic fertilizers, such as the digestate, pig slurry, or mineral fertilizers at planting. Further experiments are required to optimize the composition of feedstock used for rearing the larvae, determine the rate of application, and synchronize nutrient availability from frass with crop nutrient requirements.

\section{DATA AVAILABILITY STATEMENT}

The raw data supporting the conclusions of this article will be made available by the authors, without undue reservation.

\section{AUTHOR CONTRIBUTIONS}

MG and SD designed the study. NW and PH collected the data. MG and NW analyzed the data and wrote the manuscript. All authors contributed to improving the data analysis and writing the whole manuscript. All authors contributed to the article and approved the submitted version.

\section{FUNDING}

This study received funding from the European Union's Horizon 2020 Research and Innovation Program under Grant Agreement No. 720719.

Diener, S., Zurbrugg, C., and Tockner, K. (2009). Conversion of organic material by black soldier fly larvae: establishing optimal feeding rates. Waste Manage. Res. 27, 603-610. doi: 10.1177/0734242X09103838

EC (2010). Preparatory Study on Food Waste Across EU 27 Final Report. Brussels: European Union.

EC (2020). Circular Economy Action Plan: The European Green Deal. Brussels: European Union.

Fontaine, S., Mariotti, A., and Abbadie, L. (2003). The priming effect of organic matter: a question of microbial competition? Soil Biol. Biochem. 35, 837-843. doi: 10.1016/S0038-0717(03)00123-8

Gebremikael, M. T., Ranasinghe, A., Hosseini, P. S., Laboan, B., Sonneveld, E., Pipan, M., et al. (2020). How do novel and conventional agri-food wastes, co-products and by-products improve soil functions and soil quality? Waste Manage. 113, 132-144. doi: 10.1016/j.wasman.2020.05.040

Gebremikael, M. T., Steel, H., Bert, W., Maenhout, P., Sleutel, S., and De Neve, S. (2015). Quantifying the contribution of entire free-living nematode communities to carbon mineralization under contrasting $\mathrm{C}$ and $\mathrm{N}$ availability. PLoS ONE 10, e0136244. doi: 10.1371/journal.pone.0136244

Gold, M., Tomberlin, J. K., Diener, S., Zurbrugg, C., and Mathys, A. (2018). Decomposition of biowaste macronutrients, microbes, and chemicals in black soldier fly larval treatment: a review. Waste Manage. 82, 302-318. doi: 10.1016/j.wasman.2018.10.022

Gustavsson, J., Cederberg, C., and Sonesson, U. (2011). Global Food Losses and Food Waste: Extent Causes and Prevention, International Congress SAVE FOOD! Rome: Food and Agricultural Organization of the United Nations. 
Halloran, A., Roos, N., Eilenberg, J., Cerutti, A., and Bruun, S. (2016). Life cycle assessment of edible insects for food protein: a review. Agron. Sustain. Dev. 36, 57. doi: 10.1007/s13593-016-0392-8

Hemati, A., Aliasgharzad, N., Khakvar, R., Khoshmanzar, E., Asgari Lajayer, B., and Van Hullebusch, E. D. (2021). Role of lignin and thermophilic lignocellulolytic bacteria in the evolution of humification indices and enzymatic activities during compost production. Waste Manag. 119, 122-134. doi: 10.1016/j.wasman.2020.09.042

Houben, D., Daoulas, G., and Dulaurent, A. M. (2021). Assessment of the shortterm fertilizer potential of mealworm frass using a pot experiment. Front. Sustain. Food Syst. 5, 714596. doi: 10.3389/fsufs.2021.714596

Houben, D., Daoulas, G., Faucon, M. P., and Dulaurent, A. M. (2020). Potential use of mealworm frass as a fertilizer: impact on crop growth and soil properties. Sci. Rep. 10, 4659. doi: 10.1038/s41598-020-61765-x

IPIFF (2019). IPIFF Contribution Paper on the Application of Insect Frass as Fertilising Product in Agriculture. Brussels: International Platform of Insects for Food and Feed (IPIFF).

Joergensen, R. G. (1996). The fumigation-extraction method to estimate soil microbial biomass: calibration of the $\mathrm{k}(\mathrm{EC})$ value. Soil Biol. Biochem. 28, 25-31. doi: 10.1016/0038-0717(95)00102-6

Kuzyakov, Y. (2010). Priming effects: interactions between living and dead organic matter. Soil Biol. Biochem. 42, 1363-1371. doi: 10.1016/j.soilbio.2010.04.003

Laboan, B. (2018). Investigating the Effects of Novel Bio Fertilizers on Soil and Plant Health. Ghent: Ghent University.

Madibana, M. J., Mwanza, M., Lewis, B. R., Fouche, C. H., Toefy, R., and Mlambo, V. (2020). Black soldier fly larvae meal as a fishmeal substitute in juvenile dusky kob diets: effect on feed utilization, growth performance, and blood parameters. Sustainability 12, 9460. doi: 10.3390/su12229460

Moller, K., and Müller, T. (2012). Effects of anaerobic digestion on digestate nutrient availability and crop growth: a review. Eng. Life Sci. 12, 242-257. doi: 10.1002/elsc.201100085

Mwaniki, Z., Shoveller, A. K., Huber, L. A., and Kiarie, E. G. (2020). Complete replacement of soybean meal with defatted black soldier fly larvae meal in Shaver White hens feeding program (28-43 wks of age): impact on egg production, egg quality, organ weight, and apparent retention of components. Poult. Sci. 99, 959-965. doi: 10.1016/j.psj.2019.10.032

Nagarajkumar, M., Bhaskaran, R., and Velazhahan, R. (2004). Involvement of secondary metabolites and extracellular lytic enzymes produced by Pseudomonas fluorescens in inhibition of Rhizoctonia solani, the rice sheath blight pathogen. Microbiol. Res. 159, 73-81. doi: 10.1016/j.micres.2004.01.005

Poveda, J. (2021). Insect frass in the development of sustainable agriculture. A review. Agronomy Sustain. Dev. 41, 5. doi: 10.1007/s13593-020-00656-x

Poveda, J., Jimenez-Gomez, A., Saati-Santamaria, Z., Usategui-Martin, R., Rivas, R., and Garcia-Fraile, P. (2019). Mealworm frass as a potential biofertilizer and abiotic stress tolerance-inductor in plants. Appl. Soil Ecol. 142, 110-122. doi: 10.1016/j.apsoil.2019.04.016

Prasad, M. (2009). A Literature Review on the Availability of Nitrogen From Compost in Relation to the Nitrate Regulations SI 378 of 2006. Wexford Ireland: Environmental Protection Agency.

Quilliam, R. S., Nuku-Adeku, C., Maquart, P., Little, D., Newton, R., and Murray, F. (2020). Integrating insect frass biofertilisers into sustainable peri-urban agro-food systems. J. Insects Food Feed 6, 315-322. doi: 10.3920/JIFF2019.0049

Rodriguezkabana, R., Godoy, G., Morganjones, G., and Shelby, R. A. (1983). The determination of soil chitinase activity - conditions for assay and ecologicalstudies. Plant Soil 75, 95-106. doi: 10.1007/BF02178617

Rosmiati, M., Nurjanah, K. A., Suantika, G., and Putra, R. E. (2017). Application of compost produced by bioconversion of coffee husk by black soldier fly larvae (Hermetia illucens) as solid fertilizer to lettuce (Lactuca sativa Var. Crispa): impact to growth. Proc. Int. Conf. Green Tech. 8, 38-44.

Rossner, H. (1991). "Bestimmung der Chitinase-Aktivität," in Bodenbiologische Arbeitsmethoden, eds F. Schinner, R. Ohlinger, and E. Kandeler (Berlin: Springer), 66-70.

Rout, G. R. (2006). Effect of auxins on adventitious root development from single node cuttings of Camellia sinensis (L.) Kuntze and associated biochemical changes. Plant Growth Regul. 48, 111-117. doi: 10.1007/s10725-005-5665-1
Ruiz, B., and Flotats, X. (2014). Citrus essential oils and their influence on the anaerobic digestion process: An overview. Waste Manag. 34, 2063-2079. doi: 10.1016/j.wasman.2014.06.026

Rummel, P. S., Beule, L., Hemkemeyer, M., Schwalb, S. A., and Wichern, F. (2021). Black soldier fly diet impacts soil greenhouse gas emissions from frass applied as fertilizer. Front. Sustain. Food Syst. 5, 709993. doi: 10.3389/fsufs.2021.709993

Setti, L., Francia, E., Pulvirenti, A., Gigliano, S., Zaccardelli, M., Pane, C., et al. (2019). Use of black soldier fly (Hermetia illucens (L.), Diptera: Stratiomyidae) larvae processing residue in peat-based growing media. Waste Manage. 95, 278-288. doi: 10.1016/j.wasman.2019. 06.017

Sharp, R. G. (2013). A review of the applications of chitin and its derivatives in agriculture to modify plant-microbial interactions and improve crop yields. Agronomy 3, 757-793. doi: 10.3390/agronomy3040757

Sleutel, S., De Neve, S., Roibas, M. R. P., and Hofman, G. (2005). The influence of model type and incubation time on the estimation of stable organic carbon in organic materials. Eur. J. Soil Sci. 56, 505-514. doi: 10.1111/j.1365-2389.2004.00685.x

Tan, J. K. N., Lee, J. T. E., Chiam, Z. Y., Song, S., Arora, S., Tong, Y. W., et al. (2021). Applications of food waste-derived black soldier fly larval frass as incorporated compost, side-dress fertilizer and frass-tea drench for soilless cultivation of leafy vegetables in biochar-based growing media. Waste Manage. 130, 155-166. doi: 10.1016/j.wasman.2021.05.025

Team, R. C. (2019). R: A Language and Environment for Statistical Computing, 3.5.3 $E d n$. Vienna: R Foundation for Statistical Computing.

Van Huis, A. (2020). Insects as food and feed, a new emerging agricultural sector: a review. J. Insects Food Feed 6, 27-44. doi: 10.3920/JIFF2019.0017

Vance, E. D., Brookes, P. C., and Jenkinson, D. S. (1987). Microbial biomass measurements in forest soils - the use of the chloroform fumigation incubation method in strongly acid soils. Soil Biol. Biochem. 19, 697-702. doi: 10.1016/0038-0717(87)90051-4

Watson, C., Preißing, T., and Wichern, F. (2021a). Plant nitrogen uptake from insect frass is affected by the nitrification rate as revealed by urease and nitrification inhibitors. Front. Sustain. Food Syst. 5, 721840. doi: $10.3389 /$ fsufs. 2021.721840

Watson, C., Schlosser, C., Vogerl, J., and Wichern, F. (2021b). Excellent excrement? Frass impacts on a soil's microbial community, processes and metal bioavailability. Appl. Soil Ecol. 168, 104110. doi: 10.1016/j.apsoil.2021.104110

Zhang, K. P., Ni, Y. Y., Liu, X. J., and Chu, H. Y. (2020). Microbes changed their carbon use strategy to regulate the priming effect in an 11-year nitrogen addition experiment in grassland. Sci. Total Environ. 727, 138645. doi: 10.1016/j.scitotenv.2020.138645

Zhang, Z. G., and Yuen, G. Y. (2000). The role of chitinase production by Stenotrophomonas maltophilia strain C3 in biological control of Bipolaris sorokiniana. Phytopathology 90, 384-389. doi: 10.1094/PHYTO.2000.90.4.384

Conflict of Interest: The authors declare that the research was conducted in the absence of any commercial or financial relationships that could be construed as a potential conflict of interest.

Publisher's Note: All claims expressed in this article are solely those of the authors and do not necessarily represent those of their affiliated organizations, or those of the publisher, the editors and the reviewers. Any product that may be evaluated in this article, or claim that may be made by its manufacturer, is not guaranteed or endorsed by the publisher.

Copyright (c) 2022 Gebremikael, Wickeren, Hosseini and De Neve. This is an openaccess article distributed under the terms of the Creative Commons Attribution License (CC BY). The use, distribution or reproduction in other forums is permitted, provided the original author(s) and the copyright owner(s) are credited and that the original publication in this journal is cited, in accordance with accepted academic practice. No use, distribution or reproduction is permitted which does not comply with these terms. 